\title{
Питання психології
}

УДК 159.944 .3

DOI: $10.33099 / 2617-6858-2019-51-1-111-117$

Поканевич О. головний фахівець відділу психологічного забезпечення та соиіально-гуманітарної роботи управління персоналу Головного управління Держсавної служби з надзвичайних ситуачій Украйни у м. Києві ORCID ID 0000-0002-8948-3816

\section{ДОСЛІДЖЕННЯ ЕФЕКТИВНОСТІ ПРОГРАМИ ФОРМУВАННЯ ПСИХОЛОГІЧНОЇ ГОТОВНОСТІ ДО ПРОФЕСІЙНОЇ ДІЯЛЬНОСТІ МАЙБУТНІХ ПОЖЕЖНИХ- РЯТУВАЛЬНИКІВ}

У статті йде мова про програму формування психологічної готовності майбутніх пожежних рятувальників до професійної діяльності, прочес емпіричного дослідження илляхом констатуючого та формуючого експерименту. Описана вибірка досліджуваних, діагностична прочедура, що включас в себе експертну оцінку діяльності та діагностичний інструментарій, який був застосований для дослідження ефективності програми формування психологічної готовності. Вказаний порівняльний аналіз, який дав змогу зробити висновки про покращення показників психологічноїготовності майбутніх пожкежних - рятувальників.

Ключові слова: професійна діяльність; психологічна готовність; компоненти психологічної готовності; готовність до виконання завдань; готовність до професійної діяльності.

Постановка проблеми. Праця пожежногорятувальника відноситься до категорії складної i небезпечної для життя та здоров'я. Психологічна неготовність пожежнихрятувальників до дій в таких ситуаціях може мати погані наслідки. Як показали спеціальні наукові дослідження і досвід, при виникненні особливо складних ситуацій різко збільшується практична потреба в цілеспрямованому, кваліфікованому психологічному впливу на людей. Необхідна повсякденна психологічна готовність всього особового складу до дій в особливо складних умовах. Вона базується на професійній, психологічній, фізичній підготовленості співробітників. Однак проблеми психологічної готовності пожежнихрятувальників на початковому етапі навчання в навчальних центрах в психологічній літературі майже не досліджені.

Аналіз наукової літератури показує, що проблема, яка досліджується $є$ недостатньо розробленою в психологічній науці, а відсугність системних, науково обгрунтованих практичних рекомендацій змістовного характеру викликає істотні ускладнення в становленні ефективної системи оцінки та підтримки психологічної готовності пожежних - рятувальників до діяльності в особливих умовах.

Аналіз останніх публікацій. Ряд авторів різні аспекти проблеми оцінки та формування психологічної готовності до діяльності в екстремальних умовах розглядають в рамках проблеми психологічної підготовки. В основному вони розкривають загальні питання iii здійснення на різних етапах професійного становлення спеціаліста та грунтуються на положеннях відомих робіт А.Г.Базанова, В.П.Давидова, Л.Г. Дикої, В.Л.Марищука, В.В.Офіцерова, А.М.Столяренка, Я.Я.Юрченка, В.Т.Юсова та інших авторів.

Різні аспекти процесу оцінки та формування психологічної готовності у співробітників ризиконебезпечних професій знайшли відображення в роботах Ю.В.Аманацького, Г.С.Дуніна, А.А.Кочина, Н.Н.Силкина, Л.С.Узуна. Серед вітчизняних науковців цією проблемою займались В.В. Вареник, М.С. Корольчук, В.М. Крайнюк, С.М. Миронець, В.П. Садковий, О.В. Тімченко.

Загалом аналіз наукової літератури з цього напрямку свідчить про те, що формування психологічної готовності співробітників ДСНС повинно здійснюватись на протязі всього строку служби. Однак проблеми психологічної готовності пожежних-рятувальників на початковому етапі навчання в навчальних центрах в психологічній літературі майже не досліджені.

Аналіз наукової літератури показує, що проблема, яка досліджується $є$ недостатньо розробленою в психологічній науці, а відсутність системних, науково-обгрунтованих практичних рекомендацій змістовного характеру викликає істотні ускладнення в становленні ефективної системи оцінки та підтримки психологічної готовності пожежних-рятувальників до діяльності в особливих умовах. 


\section{Питання психології}

Аналіз проблеми психологічної готовності працівників ДСНС України до дій в екстремальних ситуаціях передбачає, насамперед, визначення основних теоретикометодологічних засад дослідження. Психологічна готовність як об'єкт дослідження стала розглядатися з 50-60-х років XX століття у зв'язку 3 підвищенням вимог до психологічних характеристик здійснюваної людиною діяльності, пошуком умов оптимізації, підвищенням іï успішності.

Загалом аналіз наукової літератури з цього напрямку свідчить про те, що формування психологічної готовності співробітників ДСНС України повинно здійснюватись протягом всього строку служби. Однак проблеми психологічної готовності пожежнихрятувальників на початковому етапі навчання в навчальних центрах в психологічній літературі майже не досліджені.

Аналіз філософської, психологічної та педагогічної літератури показав, що в сучасній науці проблема готовності до праці досліджується на наступних рівнях (Сторожук Н.А. Дисертація на здобугтя наукового ступеню кандидат психологічних наук «Формування психологічної готовності молодого офіцера збройних сил України до службово-бойової діяльності». Київ, 2010. 215с.):

- особистісному, що розглядає готовність як стійке, багатоаспектне угворення особистості, яке включає низку компонентів, адекватних вимогам змісту та умовам діяльності, які у своїй сукупності дають можливість суб'єкту успішно здійснювати діяльність i $є$ результатом підготовки (підготовленості) до певної діяльності;

- функціональному, що вивчає готовність як певний стан психічних функцій, що займає проміжне положення між психічними процесами i якостями особистості та забезпечує загальний функціональний рівень, на фоні якого розвиваються процеси, необхідні для ефективного виконання того, чи іншого виду діяльності;

- особистісно-діяльнісному, що визначає готовність як цілісний прояв всіх сторін особистості, яке дає можливість ефективно виконувати свої функції.

Ряд авторів (Кокун О.М., Пішко I.O. Лозінська Н.С., Копаниця О.В. Діагностування психологічної готовності військовослужбовців військової служби за контрактом до діяльності у складі миротворчих підрозділів: Методичний посібник. К.:НДЦ ГП ЗСУ, 2011. 153 с.) під психологічною готовністю розглядають інтегративне особистісне утворення, яке складається 3 тривалої та короткочасної готовності та забезпечує психологічну придатність військовослужбовців до виконання дій за призначенням. Тривала психологічна готовність формується впродовж тривалого часу військово-професійної підготовки та діяльності військовослужбовця та характеризує його потенційну психологічну здатність до виконання різних завдань за призначенням. Короткочасна готовність базується на основі першої та характеризує наявну на даний період часу (від дня до кількох днів) психологічну здатність до виконання конкретних завдань.

У тривалій психологічній готовності військовослужбовців автори виділяють дві основні складові: особистісну й функціональну готовність.

Особистісна готовність передбачає наявність 4-х компонентів:

- моральна готовність (усвідомлення обов'язку, відповідальність, небезпека для власного життя, соціального та особистісного сенсу участі у військовій діяльності, активна життєва позиція, самокритичність, потреба в професійному самовдосконаленні);

- вольова готовність (упевненість у собі, зібраність, організованість, сміливість, рішучість, сомоконтроль, витримка, готовність до ризику);

- комунікативна готовність (наявність загальних та професійних якостей: комунікабельність, переконливість, володіння професійною мовою, вміння віддавати чіткі команди, поваги до колег, готовність до взаємодопомоги);

- загально психологічна готовність (оптимальний рівень особистісної тривожності, високі здібності саморегуляції психічного стану, розвинуті інтелектуальні якості, розвинені здібності до планування, моделювання, програмування, оцінки результатів діяльності тощо).

У функціональну входять 6 компонентів:

- мотиваційна готовність (відданість військовій службі, потреба в самовдосконаленні,в успішному вирішенні професійних завдань, переконання в необхідності професії, бажання досягти успіху й показати себе з кращого боку та ін.);

- когнітивна готовність (знання професійних обов'язків, функцій, оцінка їх суспільної значущості, знання способів, 


\section{Питання психології}

методів, засобів вирішення професійних завдань, знання особливостей та ймовірних змін у службовій діяльності та ін.);

- креативна готовність (здатність генерувати ідеї, гнучкість розуму та ін.);

- орієнтаційна готовність (знання та уявлення про особливості й умови службової діяльності, іiі вимоги до особистості);

- операційна готовність (наявність вмінь і навичок, необхідних для вирішення професійних завдань, володіння способами й прийомами професійної діяльності, здатність до моделювання своєї діяльності);

- оцінювальна готовність (адекватна самооцінка своєї підготовленості та відповідності результатів вирішення службових задач визначеним вимогам).

Короткочасна психологічна готовність військовослужбовців до виконання дій за призначенням складається з 5-ти компонентів:

- мотиваційна готовність (мотивація на виконання завдань за призначенням);

- орієнтаційна готовність (знання та уявлення про особливості й умови діяльності, вирішуваних завдань, вимог, які вона ставить до особистості віцськовослужбовця);

- операційна готовність (актуальна можливість до реалізації наявних умінь та навичок, необхідних для вирішення професійних завдань);

- оцінювальна готовність (адекватна самооцінка своїх можливостей щодо вирішення поставлених задач);

- емоційна готовність (оптимальний рівень ситуативної тривожності, позитивна настроєність на вирішення завдань за призначенням, зібраність, впевненість у своїх силах та ін.).

Отже, стійку, тривалу готовність особистості до діяльності можна розглядати як складну індивідуальну властивість особистості. Ïї формування відбувається в процесі діяльності опосередковано, через створення $\mathrm{i}$ повторення спеціально розроблених розвивальних ситуацій, психологічних умов. При цьому прості психічні стани, властивості особистості певним чином пов'язуються одна 3 одною, інтегруються і утворюють нову складну структуру.

На думку багатьох авторів (М. Дьяченка та Л. Кандибович), психологічна готовність до діяльності, як правило, проявляється в екстремальних умовах i залежить від типу нервової системи, індивідуально-типологічних особливостей особистості.
Отже, під психологічною готовністю до професійної діяльності ми будемо розуміти складне цілісне утворення психіки людини, що інтегрує в собі низку психологічних феноменів, які знаходяться в тісному взаємозв'язку, має складну динамічну структуру, між компонентами якої існують функціональні зв'язки. Залежно від того, яке функціональне навантаження виконують змістові характеристики даного феномену в процесі професійної діяльності, їх можна віднести до певних «блоків», а саме компонентів психологічної готовності до професійної діяльності. Рівень психологічної готовності у майбугніх пожежних-рятувальників ДСНС стає можливим оцінити безпосередньо в процесі навчання на курсах початкової підготовки. Аналізуючи компоненти психологічної готовності до діяльності в особливих умовах, варто виокремити з-поміж них чотири найважливіші:

- мотиваційний: складна система мотивів, що скеровують, посилюють і зумовлюють активність фахівця ДСНС у професійній діяльності;

- комунікативний: наявність загальних та професійних якостей: комунікабельність, переконливість, володіння професійною мовою, вміння надавати чіткі команди, поваги до колег, готовність до взаємодопомоги;

- вольовий: упевненість у собі, зібраність, організованість, сміливість, рішучість, самоконтроль, витримка, готовність до ризику;

- моральний: усвідомлення обов'язку, відповідальність, небезпека для власного життя, соціального та особистісного сенсу участі у військовій діяльності, активна життєва позиція, самокритичність, потреба в професійному самовдосконаленні.

Отже, проведений аналіз літературних джерел дав нам змогу зрозуміти, що процесу формування психологічної готовності майбугніх пожежних-рятувальників під час їх навчання на курсах початкової підготовки приділено дуже мало уваги. Наукові роботи по дослідженню психологічної готовності у більшості свой присвячені формуванню психологічної готовності майбугніх офіцерів, підготовка яких відбувається у вищих навчальних закладах системи ДСНС України i триває п'ять років.

Мета статті: охарактеризувати програму формування психологічної готовності пожежних-рятувальників до майбугньої діяльності, створену автором та описати 


\section{Питання психології}

результати емпіричного дослідження, які були отримані у процесі впровадження вказаної програми у практичну діяльність навчального центру підготовки майбугніх пожежних рятувальників.

Виклад основного матеріалу. 3 метою визначення моделі психологічної готовності майбугніх пожежних рятувальників автором була розроблена анкета, яка включала в себе різні компоненти психологічної готовності майбугніх пожежних-рятувальників, які описувались вище. У анкетування прийняли участь 30 осіб начальницького складу (начальники районних управлінь, начальники частин, начальники караулів), яким було запропоновано (враховуючи досвід їх роботи, напрямок реагування в екстремальних ситуаціях) визначити найбільш значущі на їх думку компоненти психологічної готовності пожежних-рятувальників до майбугньої діяльності, які необхідно визначити, сформувати або закріпити під час навчання на курсах початкової підготовки. Аналіз проведеного анкетування дозволив створити модель психологічної готовності майбутніх пожежних рятувальників до діяльності в особливих умовах. В результаті дослідження була розроблена програма формування психологічної готовності пожежнихрятувальників до дій за призначенням, яка передбачає максимальне врахування особливостей професійної діяльності на початковому етапі навчання.

Вибірку склали 34 особи - чоловіки віком від 20 до 32 років, які не мали досвіду підготовки до діяльності в екстремальних умовах, не мають досвіду служби у Збройних силах України, рівень освіти яких середній та середньо - спеціальний. Всі учасники дослідження пройшли професійний відбір на службу, відповідне психологічне тестування та були спрямовані для проходження первинної професійної підготовки і отримання кваліфікації «пожежний-рятувальник». Ніхто 3 них раніше не брала участь у ліквідації надзвичайної ситуації.

Організаційно формувальний експеримент складався з трьох етапів:

1) первинна комплексна діагностика професійно-значущих рис та властивостей, що складають психологічну готовність до діяльності в особливих умовах.

2) реалізація формувального впливу (17 навчальних годин теоретичної та практичної підготовки).
3) вторинна діагностика психологічних рис та властивостей - компонентів психологічної готовності до діяльності в особливих умовах (за допомогою тих самих методик). Тривалість періоду часу між перших та другим тестуванням складала 16 тижнів, що відповідає терміну навчання.

Для дослідження були підібрані методики, що дозволяють оцінити вплив різних факторів професійної діяльності рятувальників не тільки в умовах підготовки, але й безпосередньої участі в ліквідації надзвичайної ситуації. Під час організації дослідження бралися до уваги психометричні якості інструменту, а також можливість його використання в груповому обстеженні працівників підрозділів ДСНС України. Діагностичний комплект склали наступні особистісні опитувальники: багатофакторний особистісний опитувальник 16 PF P. Кеттелла (форма C), методика діагностики міжособистісних відносин Т. Лірі, ссобистісний опитувальник ЕРІ Г. Айзенка, скорочений багатофакторний опитувальник дослідження особистості Міні-мульт, опитувальник «Комунікативні та організаторські здібності» (КОС), індивідуально-типологічний опитувальник Л. M. Собчик, опитувальник структури темпераменту (ОСТ) В. М. Русалова, особистісний опитувальник ЛеонгардаШмішека. Наприкінці навчання (через чотири місяці) було проведене повторне тестування курсантів за допомогою того самого набору психологічних методик. Проаналізовані зміни індивідуальних результатів кожного учасника експерименту, їx напрямок та виразність. Щодо кожного зроблені висновки про загальну сформованість психологічної готовності до особливих умов діяльності наприкінці навчання.

Висновки i перспективи подальших досліджень: в результаті емпіричного дослідження стало можливим описати характерні особливості пожежнихрятувальників, що визначають рівень готовності до діяльності в екстремальних умовах. Відмічена виразна динаміка індивідуальних якостей курсантів, що свідчить про формування психологічної готовності до особливих умов діяльності.

- Достовірно зменшується чутливість до зовнішніх загроз. Відмічається загальне зменшення емоційності як функціональної властивості: чутливості до невдач у роботі, до розбіжностей між запланованим i реальним 


\section{Питання психології}

результатом, внаслідок чого пожежні стають впевненіші і спокійніші. Опитувані стали швидше та сміливіше приймати самостійні рішення, сформувалась готовність до ризику, співпраці з незнайомими людьми в незнайомих обставинах.

Корегується тривожно-помисливе переживання власних невдач, емоційнодепресивні прояви, формується обгрунтована впевненість в собі і в своїх силах. Майбутні пожежні-рятувальники поступово вчаться керувати своїми невдачами, не сприймати поразки у діяльності як внутрішній конфлікт; уникати тривожного каяття та почугтя провини. Зменшуються прояви песимізму та пасивності, зникає загальмованість, інертність реакцій, усувається невпевненість, відчуття безсилля перед стресовими факторами

- Знижується екстремально-високий рівень домінантності у міжособистісних стосунках, натомість проявляться орієнтація на тісне співробітництво в групі. Гіперсоціальні альтруїстичні установки курсантів також знижуються до оптимального рівня. Вони відповідальні по відношенню до людей, вміють співчувати, заспокоїти або підбадьорити, при цьому здатні знаходити i підтримувати баланс інтересів в міжособистісній взаємодії.

- Самооцінка стає більш адекватною, залишаючись в межах адаптивного рівня. Внаслідок близького знайомства з професією, 3 ii перевагами та ризиками, сугтєво зменшується нереалістично-романтична спрямованість професійних уявлень курсантів, руйнуються ілюзії. Важливо надати цій кризі належний психологічний супровід, щоб не відбулося розчарування у виборі професії, натомість первинна романтична мотивація трансформувалася в реалістично-практичну налаштованість на вирішення професійних завдань.

- Розвивається загальна нервово-психічна стійкість, нормативність та самоконтроль поведінки. Паралельно з цим відбувається набугтя експресивності та життерадісності. Емоційний фон опитаних оптимізуються, його можна охарактеризувати як незначне підвищення активності. Помірна «енергетизація» курсантів має позитивний ефект впливу на мотивацію досягнень та ефективність навчання. Підвищений фон настрою виступає внутрішнім адаптивним ресурсом діяльності в особливих умовах.
Змінюється міжособистісної поведінки, формується гнучкість у вирішенні проблем і конфліктних ситуацій. Відбувається достовірний зсув даних виміру «самодостатність - соціабельність». Опитувані стали менш схильні підкорятися зовнішньому впливу без урахування ситуації. Конформізм, орієнтація на соціальне схвалення замінюється на усвідомлений вибір лінії поведінки: орієнтацію на власні рішення, самостійність, прагнення мати власну думку (залишаючись при цьому пов'язаним із іншими членами команди) та здатність за потреби проявити опір. 3 іншого боку, відбувається нормалізація рівня агресивності частини курсантів, знижується вимогливість, прямолінійність, деяка різкість та суворість в оцінці інших людей.

Достовірно збільшується сміливість та ефективність в соціальних контактах, зростає рівень комунікативних i організаторських здібностей. Це запорука швидкої орієнтації у новій обстановці, знаходження контакту у спілкуванні з незнайомими людьми, прийняття самостійних рішень та організації ефективної допомоги в екстремальній ситуації. Після проходження підготовчої програми сугтєво зростає показник соціальної ергічності - у опитуваних формується новий рівень потреби в соціальних контактах, прагнення до лідерства, відбувається освоєння соціальних форм діяльності, схильність до сприйняття світу через комунікацію. Майбугні рятувальники стають більш наполегливі; самі починають шукати справи і завдання, що б задовольняли їх потребу в комунікації i організаторській діяльності.

Структура міжособистісних стосунків курсантів загалом стає більш унормованою, гнучкою та збалансованою. При цьому формується професійна модель комунікативної поведінки, для якої характерне поєднання високої соціальної ергічності та темпу 3 помірною пластичністю, a також дещо зниженою емоційністю та імпульсивністю. Пожежні усвідомлюють важливість соціальних зв'язків та власну потребу в них, достатньо легко й невимушено вступають в контакти 3 незнайомими людьми, використовуючи при цьому різноманітні комунікативні програми. При вступі в комунікацію вони певний час обмірковують ситуацію, а потім швидко висловлюються (в процесі професіоналізації ці комунікативні шаблони станугь автоматизованими). Формується впевнений та 


\section{Питання психології}

спокійний стиль спілкування, що базується на переструктуруванні наявних функціональних властивостей темпераменту. Така модель поведінки обгрунтована необхідністю вирішення професійних завдань в екстремальних умовах діяльності.

Таким чином, емпірична перевірка переконливо засвідчила ефективність розробленої формування комплексної психологічної програми пожежних-рятувальників до діяльності в особливих умовах. Запропонована програма може бути рекомендована до впровадження на початковому етапі навчання в системі Державної служби 3 надзвичайних ситуацій України.

\section{Список використаних джерел}

1. Капустина А. Н. Многофакторная личностная методика Р. Кеттелла. СПб. Речь, 2001. 112 с.

2. Порядок психологічного забезпечення в Державній службі України з надзвичайних ситуацій: Наказ Міністерства внутрішніх справ України № 747 від 31.08.2017. URL: http://zakon0.rada.gov.ua/laws/show/z1390-17

3. Бурлачук Л. Ф. Словарь-справочник по психодиагностике. 3-е изд. СПб. Питер, 2007. 688 с.

4. Головей Л. А. Кризисы развития субъекта деятельности на начальных этапах профессионализации. Вестник Московского университета. Серия 14: Психология. 2016. № 4. С. 47-54.

5. Зеер Э. Ф. Психология профессий: учеб. пособие. Москва. Мир, 2006. 336 с.

6. Кокун О. М. Психологія професійного становлення сучасного фахівця. Київ. Інформ.-аналіт. агенство, 2012. $200 \mathrm{c}$.

7. Собчик Л. Н. Психология индивидуальности. Теория и практика психодиагностики. СПб. Речь, 2008. 624 с.

8. Сокращенный многофакторный опросник для исследования личности. URL: http://psylab.info

9. Выбойщик И. В. Акцентуации характера : учеб. пособ. 2-е изд., испр. и доп. Челябинск, ЮУрГУ, $2007.84 \mathrm{c}$.

\section{References}

1. Kapustina A.N. Multifactorial personal method R.Kettella. Speech, 2001. 112 p.

2. The order of psychological protection in the State Services of Ukraine for the most advanced situations: Mandate of the Ministry of Internal Affairs of Ukraine No. 747 from 31.08.2017 URL: http://zakon0.rada.gov.ua/laws/show/z1390-17.

3. Burlachuk L.F. Psychological Diagnostics Reference Book. 3rd ed. SPb. Peter, 2007. 688 p.

4. Golovey L. A. Development Crises in the Initial Stages of Professionalization. Moscow University Herald. Series 14: Psychology. 2016. № 4. p. 47-54.

5. Zeer E.F. Psychology of professions: studies. Manual. M.: Mir. 2006.336 p.

6. Kokun O. M. Psychology of a professional establishment of a specialist. K. Inform.-analit. agency. 2012. 200 p.

7. Sobchik L.N. Psychology of individuality. Theory and practice of psycho diagnostics. SPb. Speech, 2008. 624 p.

8. Abbreviated multi-factor questionnaire for the study of personality. Material Psylab.info - encyclopedias psychodiagnostics. URL: http://psylab.info

9. Vyboyshchik I. V. Accentuation of character: studies. benefit. 2nd ed., Corr. and add. Chelyabinsk: Publishing house SUSU. 2007. 84 p.

\section{Резюме}

Поканевич Е. главный специалист отдела психологического обеспечения и соииально - гуманитарной работы управления персонала Главного управления Государственной службы по чрезвычайным ситуачиям Украины в г. Киеве. ORCID ID 0000-0002-8948-3816

\section{ИССЛЕДОВАНИЕ ЭФФЕКТИВНОСТИ ПРОГРАММЫ ФОРМИРОВАНИЯ ПСИХОЛОГИЧЕСКОЙ ГОТОВНОСТИ К ПРОФЕССИОНАЛЬНОЙ ДЕЯТЕЛЬНОСТИ БУДУЩИХ ПОЖАРНЫХ - СПАСАТЕЛЕЙ}

В статье идет речь опрограмме формирования психологической готовности будуииххпожсарньхх - спасателейк профессиональной деятельности, прочесс эмпирического исследования путем констатируютего и формируюоеео эксперимента. Описана выборка испьтуеемьх, диагностическая прочедура, включающая в себя экспертнуюо оченку деятельности и диагностический инструментарий, которьй был применен для исследования эффекктивности програмль формарования психологической готовности. Указанньй сравнительньй анализ, которьій позволил сделать выводы об улучиении показателей психологическойготовности будуиих поэнарныхх - спасателей.

Ключевые слова: профессиональная деятельность; психологическая готовность; компонентьь психологической готовности; готовность $к$ выполнению задач; готовность $к$ профессиональной деятельности. 


\title{
Питання психології
}

\author{
Summary \\ Pokanevych $\boldsymbol{O}$. A leading specialist, the department \\ of psyhological maintanence and sociological and humanitarian \\ work of personnel management in the Head administration \\ of the State Emergency Service in Kyiv. \\ ORCID ID 0000-0002-8948-3816 \\ THE PROGRAMME OF FORMING PSIHOLOGICAL READINESS FOR PROFESSIONAL \\ ACTIVITY OF FUTURE FAIR RESCUERS AND ITS EFFECTIVENESS RESEARCH
}

The article covers the programme of forming psihological readiness for professional activity of future fair rescuers for professional activity, the process of empiric research by means of statical and forming experiment. It presents the description of the chosen and the diagnostic tools applied to study the effectiveness of the programme of forming psihological readiness. Described is the comparative analysis which helped to make conclusions about improved indexis of psihological readiness of future fair rescuers.

Introduction: the analysis of scientific literature shows that the problem which is being investigated is not developed enough in psihological science and the lack of systematic practical recommendations of a substantive nature causes complications in the formation of an effective system of assessment and support of the psihological readiness of firefighters to operate.

Purpose: purpose is to characterize the formation program of psihological readiness of firefighters to the future activity created by the author and to describe the results of empiric research which where received in the process of implementation of the above mentioned program into practical work of future firefighters training centre.

Methods: the analysis of philosophical, psihological and pedagogical literature shows, that in modern science. The problem of readiness to operate is being investigated at the following levels: personal, functional and that of personal activity. For research were selected methods that allow to evaluate the impact of different factors of professional rescue workers not only in terms of training but also in direct participation in the elimination of an emergency. During the organization of the study, attention was paid to the psychometric qualities of the instrument and the group survey of employees of the units of the state emergency situations service of Ukraine.

Originality: the content and regularitie of the formation of the psihological readiness of fire rescuers for activities in special conditions at the initial stage of training are described: - the dependence on the effectiveness of the performance of official duties on the formation of psihological readiness at the initial stage of the service is clarified; in the process of theoretical and experimental study of the process of formation of the psihological readiness for professional activity, psihological peculiarities of specialists of the research sample are shown, their connection with the objective conditions of education and the individual - psihological level of readiness for activities in risk conditions are considered; - the basis of creation of the system of means of preparation of the psihological readiness for professional activity, for action in extreme situations is determined.

Conclusion: as a result of the study, it was possible to describe the specific features of firefighters that determine the level of readiness for activities in extreme conditions. The generalized psihological portrait of future fire rescuers of the initial stage of training includes the following features: the communicative aspect, the motivational value aspect, the emotional aspect, the aspect of volitional regulation, cognitive aspect, the moral aspect. Empirical data obtained allow us to substantially clarify the theoretical model of psihological readiness for activities under special conditions.

Key words: professional activity; psihological readiness; components of psihological readiness; readiness for fulfillment of tasks; readiness for professional activity. 